\title{
CORRELATION BETWEEN DIFFERENT MOTOR ABILITIES AND SCORE POINTS IN THE RAUCH CUP
}

\author{
Špela BOGATAJ ${ }^{1}$, Blaž LEŠNIK ${ }^{1}$ \\ ${ }^{1}$ University of Ljubljana, Faculty of Sport, Slovenia \\ Corresponding author: \\ Špela BOGATAJ \\ University of Ljubljana, Faculty of Sport, Slovenia \\ Phone: +38640415766 \\ e-mail: sspelabogataj@gmail.com
}

\section{ABSTRACT}

In alpine skiing, like in other sports, achieving good results depends on a variety of factors and the quality of planning and conducting the process of training. The purpose of the research was to determine whether there is a correlation between the selected motor tests and the number of points achieved in Rauch Cup. The research was conducted on a sample of 41 male competitors from different ski clubs across Slovenia. The following tests were conducted on our selected group of 13-to 14-year old males: taping with a dominant leg, test of stability, run from a flying start (maximum speed), ten jumps on both legs, 400-metre run, running nines, counter-movement jump and reaction time to a visual impulse (squat jump). The linear regression analysis was used to determine the relationship between the selected motor tests and performance in alpine skiing (Rauch Cup points). Correlation was found between each individual motor test and criterion variable (Rauch Cup points) except test of stability and reaction time test (squat jump). Multiple linear regression (MLR) showed us that the selected model, assembled of four tests that gave the highest MLR was significant $(R=.727 ; p$ $<.001)$. According to the findings, we can conclude that motor skills represent $53 \%$ of the competitive performance variance of the alpine skier.

Keywords: alpine skiing, competition, motor functions, performance. 


\section{POVEZAVA RAZLIČNIH MOTORIČNIH SPOSOBNOSTI Z DOSEŽENIMI TOČKAMI V RAUCH POKALU}

\section{IZVLE ̌̌EK}

Pri alpskem smučanju je doseganje dobrih rezultatov, enako kot tudi pri drugih športnih disciplinah, odvisno od različnih dejavnikov in kakovosti načrtovanja ter izvajanja trenažnega procesa. Namen naše raziskave je ugotoviti, ali obstaja korelacija med rezultati $v$ izbranih motoričnih testih in številom doseženih točk $v$ Rauch pokalu. $V$ raziskavo smo vključili 41 moških tekmovalcev, starih od 13 do 14 let, iz različnih slovenskih smučarskih klubov. Izvedli smo sledeče teste: taping z dominantno nogo, test stabilnosti, tek z letečim štartom (maksimalna hitrost), deseteroskok sonožno, tek na 400 metrov, osmice med devetimi keglji, skok z nasprotnim gibanjem in reakcijski čas na vizualni impulz (skok iz polčepa). S Pearsonovim koeficientom smo določili linearno razmerje med motoričnimi testi in kriterijsko spremenljivko (dosežene točke $v$ Rauch pokalu). Regresijska analiza je bila uporabljena za določitev hipotetičnega vpliva celotnega spektra izbranih motoričnih sposobnosti na uspešnost pri alpskem smučanju. Korelacijska analiza med posameznimi testi in kriterijsko spremenljivko je pokazala, da vsi testi razen testa stabilnosti in reakcijskega časa na vizualni impulz, medsebojno korelirajo. Multipla regresija nam je pokazala, da je regresijski model, sestavljen iz štirih izbranih spremenljivk, značilen $(R=.727 ; p<.001)$. Glede na ugotovitve lahko trdimo, da motorične sposobnosti predstavljajo velik delež tekmovalne uspeřnosti v alpskem smučanju, zato bi morali redno testiranje vključiti v program treninga in evalvacije.

Ključne besede: alpsko smučanje, tekmovanje, motorika, tekmovalna uspešnost

\section{INTRODUCTION}

Good psychophysical preparation is one of the basic conditions for achieving good results at competitions. That is why this part requires extra attention in younger as well as in older categories of competitors. The potential of the psychosomatic status of an alpine skiing competitor depends on the development of their motor skills, which also represents a basic guideline for designing a training process with content that is as closely as possible related to the quality of movement in alpine skiing. Depending on this, we need to define a method to help us monitoring positive or negative changes which result from both the content and intensity of the training process (Šturm, 2012). Coaches should perform regular tests of their athletes aiming to obtain valid results for efficient and healthy athlete's development and health (Ušaj, 2003).

Alpine skiing is a complex sport discipline which requires basic muscular power, aerobic and anaerobic abilities as well as a wide movement program of specific motor 
abilities. The contribution level of each factor depends on the competition demands in which the athlete takes part. Some sports, like swimming or track, are performed in a controlled environment and there the demands of competition can be quantified quite easily. On the other hand, sports like alpine skiing or football are exposed to various external influences and an athlete must often adapt to them in the middle of their performance (Heikkinen, 2003).

If we want to develop an appropriate battery of tests for alpine skiers, we need to understand which muscles are used during a competition and in what way (the type of contraction). During these tests, the athletes need to stimulate those muscles in the same way as they do at the competition. Hintermeister et al. (1995) conducted research involving elite skiers and found out that their lower body and torso musculature was heavily activated during the alpine skiing movements. Throughout a turn, adductors and some other muscles were working almost continuously at over $100 \%$ of maximum voluntary rate of contraction. Brown and Wilkinson (1983) state that alpine skiers have, in comparison with untrained general population, lower body fat and that their body composition is similar to weight lifters' and swimmers'. A study conducted by Haymes \& Dickinson (1980) documented that alpine skiers have high ranking of isokinetic leg strength. The conclusion from these results suggests that lower body strength is an important predictor of a successful alpine ski competitor. This can help us conduct a proper battery of tests for alpine skiers.

There is not a lot of research done with younger populations in alpine skiing correlating competition performance and field or laboratory tests. Mladenović et al. (2015) investigated the correlation between results in ten motor ability tests and achieved level of ski knowledge during six-day alpine ski school in children aged between 7 and 8 . They found that successful children have better developed agility, coordination, strength and frequency of movement. Bandalo and Lešnik (2011) studied a correlation, based on a model of potential and competitive performance, on a sample of 30 older boys aged from 13 to 14 who participated in the Argeta Cup 2009 / 2010 and showed 4 correlations of anthropometric dimensions and 13 correlations of motor dimensions. Dolenec and Lešnik also found an important correlation between competition success and morphology and motor abilities in young female (Dolenec, 1996) and young male competitors (Lešnik, 1996) in alpine skiing. Based on the results they concluded that it would be reasonable to reduce the number of variables from battery of tests.

According to these findings, we have put together a potentially successful battery of tests that measure those motor skills that are most associated with competitive performance. As Dolenec (1996), Bandalo and Lešnik (2011) and Lešnik (1996) suggested, we have reduced the number of motor variables from eighteen to eight variables. We set the following research questions: i.) is there a correlation between selected motor tests and points achieved in Rauch Cup in male U14 age class and ii) does the selected model of four variables has a correlation with points achieved in the Rauch Cup. 


\section{METHODS}

\section{Participants}

The sample consisted of 41 boys who were competing in Rauch Cup (slalom, giant slalom and super-G) in season 2016 / 17 in U14 age class. They came from different ski clubs across Slovenia. The Ethical Board of the Faculty of Sport, University of Ljubljana, approved the research experiment. All participants were informed of the study purpose and voluntarily participated in all tests. Parental written agreement was also obtained for each participant.

\section{Procedure}

Measurements were assessed in autumn, before the competition season started. The whole procedure and tests were explained prior to the start of measurements. Tests were conducted at the Faculty of Sport in Ljubljana. The athletes were properly warmed-up before the start. First we assessed basic anthropometric measurements, body height and body weight. Then we used the following motor tests:

\section{Taping with a dominant leg (TAP)}

This represents the rate of movements test and is performed by shifting one's foot as quickly as possible over a $15-\mathrm{cm}$-high bar within $15 \mathrm{sec}$. The athlete sits on a chair with arms along his torso. One full cycle consists of moving the foot over the bar, touching the ground and returning the foot to its original position. The device counts only fully completed cycles and our research consisted of each athlete having two attempts, with the better of the two taken into account.

\section{Test of stability (STAB)}

The athlete had two attempts for this test, which was used to assess the overall dynamic stability and was performed in laboratory with Biodex Balance SD. The result is presented in the form of stability index. The athlete was positioned with both legs on the device's platform and attempted to maintain the stable position for as long as possible. 
Špela BOGATAJ, Blaž LEŠNIK: CORRELATION BETWEEN DIFFERENT MOTOR ABILITIES AND SCORE POINTS ..., 35-44

\section{Run from the flying start - maximum speed (MAXSP)}

The athletes had two attempts and were asked to start in the ski stance position. On starting mark athlete must in $30 \mathrm{~m}$ develop maximum speed. The results are measured in $\mathrm{m} / \mathrm{s}$ by a laser device, maximum speed achieved during running was recorded.

\section{Ten jumps on both legs (MSKOK10)}

This test measured driving power of the legs, with each athlete having two attempts and the longest of the two was taken into analysis. The test involved the measurement of the distance achieved by 10 consecutive jumps with no interruption between repetitions.

$400 m$ run (MT400)

Speed endurance was assessed by 400 meters run test. Athletes performed this test only once.

\section{Running nines (SKI9)}

The task here was to run as quickly as possible around nine pins (in the form of an eight) and represents a test of agility. This test was performed only once.

\section{Counter movement jump (CMJ)}

In this test, the athletes had to jump as high as possible using countermovement jumping technique (CMJ). They had three trial jumps followed by two recorded attempts. There was a 2-minute rest between each jump, with jumps being performed on a ground-force plate. The height was calculated based on the flight time. The highest jump was taken into account.

\section{Reaction time to a visual impulse (squat jump) (SJREAC)}

Reaction time to a visual impulse triggered by computer screen was measured using Optojump device. On a visual signal, the athlete had to jump as quickly as possible from a squat position. They had three trial jumps followed by two recorded attempts. 


\section{Criterion variable (points in Rauch Cup)}

The criterion variable represents the actual performance of all measured competitors on Rauch Cup in the 2016 / 2017 season. This was expressed by the total number of points, achieved in each individual competition for Rauch Cup.

\section{Statistical Analysis}

Collected data was analysed using SPSS (IBM, version 22, USA) and Microsoft Excel 2013 and we summarized data with descriptive statistics. With Pearson's correlation coefficient we determined the linear correlation of each individual variable with competitive performance (Rauch Cup points). The multiple linear regression (MLR) analysis was used to determine how multiple independent variables are related to one dependent variable, in our case to competitive performance. With Enter method we inserted four variables that gave the highest MLR, with that we predicted the level of effect of this model and each variable on criterion variable. The criterion variable was represented by the total number of points, achieved in the Rauch Cup. Statistical significance was accepted at $\mathrm{p}<.05$.

\section{RESULTS}

Participant's basic anthropometric data are presented in Table 1.

Table 1: Basic anthropometric data.

\begin{tabular}{|l|c|}
\hline & AM \pm SD \\
\hline $\mathbf{N}$ & 41 \\
\hline Body height (cm) & $158.2 \pm 9.3$ \\
\hline Body mass (kg) & $49.5 \pm 11.7$ \\
\hline
\end{tabular}

In Table 2 we determined for each variable minimum value, maximum value, range of values and arithmetic mean \pm standard deviation. 
Table 2: Descriptive statistics for each variable.

\begin{tabular}{|l|c|c|c|c|}
\hline & RANGE & MIN & MAX & AM \pm SD \\
\hline Taping with the dominant leg & 9.0 & 17.0 & 26.0 & $22.0 \pm 2.3$ \\
\hline Test of stability & 6.6 & 1.3 & 7.9 & $3.9 \pm 1.8$ \\
\hline Maximum speed & 2.47 & 5.39 & 7.87 & $6.64 \pm .55$ \\
\hline Ten jumps on both legs & 11.1 & 15.2 & 26.3 & $19.6 \pm 2.4$ \\
\hline 400m run & 41.7 & 62.1 & 103.8 & $79.8 \pm 9.6$ \\
\hline Running nines & 11.6 & 28.1 & 39.7 & $33.0 \pm 2.8$ \\
\hline Counter-movement jump & 22.5 & 18.6 & 41.1 & $27.6 \pm 4.8$ \\
\hline Reaction time to a visual impulse & .23 & .39 & .62 & $0.47 \pm .06$ \\
\hline
\end{tabular}

Note: Range - the range between minimum and maximum value, MIN - minimum value, $\mathrm{MAX}$ - maximum value, $\mathrm{AM} \pm \mathrm{SD}$ - arithmetic mean with standard deviation.

Table 3: Pearson correlation coefficient values between motor variables and performance (points) in the Rauch Cup.

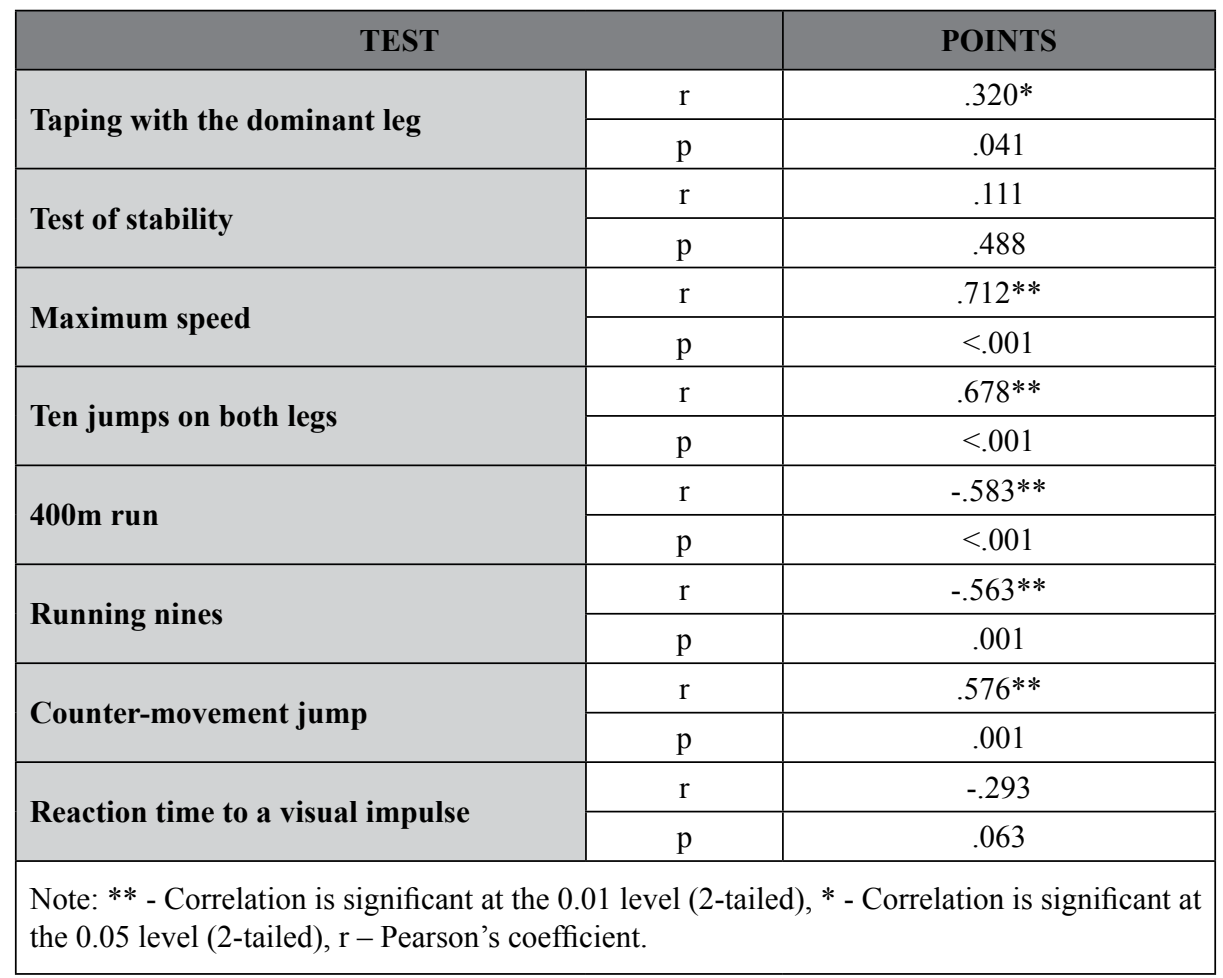


Table 3 presents Pearson's correlation coefficients for the motor tests in relation to skiing performance. We found positive correlation between criterion variable and variables TAP, MSKOK10, MAXSP and CMJ, while negative for MT400 and SKI9. In the case of SJREAC and STAB, the correlation coefficient calculation did not show a significant correlation.

Multiple linear regression (MLR) analysis was performed with Enter method. We included 4 predictors that gave the highest MLR for our sample of 41 participants. These were MAXSP, MSKOK10, MT400 and CMJ. Results showed that the linear relationship, between four motor tests and skiing performance is high $(\mathrm{R}=.727$; $\mathrm{P}<$ .001 ) and explained $53 \%$ of skiing performance variance (Table 4).

Table 4: Model.

\begin{tabular}{|c|c|c|}
\hline $\mathbf{R}$ & $\mathbf{R}^{2}$ & $\mathbf{P}$ \\
\hline .727 & .53 & $<.001$ \\
\hline $\begin{array}{l}\text { Note: R - coefficient of multiple correlation; } \mathrm{R}^{2} \text { - coefficient } \\
\text { (Constant), MAXSP - run from the flying start (max. speed), MSKOK10 - ten jumps on both } \\
\text { legs, MT400 - 400m run, CMJ - counter-movement jump. }\end{array}$ \\
\hline
\end{tabular}

Table 5: The multiple linear regression (MLR) analysis.

\begin{tabular}{|l|c|c|c|c|}
\hline & B & Beta & Partial R & P \\
\hline Constant & -1773.776 & & & .033 \\
\hline Maximum speed & 199.497 & .613 & .342 & .036 \\
\hline Ten jumps on both legs & 24.375 & .325 & .178 & .284 \\
\hline 400m run & 2.917 & .156 & .113 & .498 \\
\hline Counter-movement jump & -2.373 & -.063 & -.046 & .784 \\
\hline
\end{tabular}

Note: dependent variable: Pokal; predictors: (Constant), MAXSP - run from the flying start (max. speed), MSKOK10 - ten jumps on both legs, MT400 - 400m run, CMJ - counter-movement jump.

In Table 5 we can see that when we add four variables into MLR analysis, some of them are not significant anymore. In our case, the variable MAXSP is the most important contributor $(\mathrm{p}=.036)$. 


\section{DISCUSSION}

This study was focused on the correlation between the selected motor abilities and competitive performance in U14 age group of alpine skiers. We found a correlation between competitive performance and results in six out of eight motor tests. Positive correlation was found between Rauch points and variables TAP, MSKOK10, MAXSP and CMJ, while negative for MT400 and SKI9. The same as Bandalo and Lešnik (2011), we also did not find a significant correlation between balance (variable STAB) and criterion variable. This is interesting because the postural control in alpine skiing, in particular the management of the balance, is widely considered as one of the limiting factors of performance. For future research, we suggest that researchers use different balance tests and find out which test is best correlated with performance. In multiple linear regression, we included 4 predictors that gave the highest MLR: MAXSP, CMJ, MSKOK10 and MT400. Simple linear regression showed us that each predictor variable had a significant p-value. But from the multiple regression model output, CMJ, MSKOK10 and MT400 no longer displayed a significant p-value. We think this is an example of collinearity of the predictors. But overall, the model is still significant. In our case, the variable MAXSP, which represents maximum speed, had a strongest correlation with the criterion. With our research we addressed the dilemma with using a greater or smaller battery of test. As Lešnik (1996) and Dolenec (1996) suggested, we used a smaller battery, which can be performed at once. Based on the test results we can plan and conduct the training process, which later leads to efficient effort overcoming at training and at competitions. In future, it will be necessary to monitor the development of young athletes even more systematically. This is a sensitive period and that is why it is even more important that the battery of tests is effective and tells us those things about the athlete, which professionals needs in order to guide them in the training process. Nowadays, the differences between individuals' performance are getting smaller, that is why we need to focus on raising the level of motor and functional skills to the highest level possible. In this part, testing motor abilities plays an important role. Although highly developed motor abilities are crucial for good competitive performance, we must not ignore the role of biological age, motivation and concentration for this age group.

\section{CONCLUSION}

Our findings show the suitability of selected motor tests in determining the potential success of young alpine skiers. We will continue with deployment of state-of-the-art measurement methods and try to connect them with the measurements of older age categories of competitors in alpine skiing. In conclusion, the test concepts presented in this study can help ski schools, clubs and skiing federations in the guidance and evaluation of young talents. In the future, we suggest that in addition to motor test, researches also include several anthropometric measures and examine cognitive and behavioural measures of motivation. 


\section{REFERENCES}

Bandalo, M. \& Lešnik, B. (2011). The connection between selected anthropometric and motor variables and the competitive success of young competitors in alpine skiing. Kinesiologia Slovenica, 17(3), 16-31. VIEW ITEM

Brown, S. L., \& Wilkinson, J. G. (1983). Characteristics of national, divisional, and club male alpine ski racers. Medicine and Science in Sports and Exercise, 15(6), 491-495. VIEW ITEM

Dolenec, M. (1996). Vrednotenje modela uspešnosti mlajših deklic v alpskem smučanju [Evaluation of the model of success of young girls in Alpine skiing] (Unpublished master's thesis), Faculty of Sport, University of Ljubljana, Slovenia.

Haymes, E. M., \& Dickinson, A. L. (1980). Characteristics of elite male and female ski racers. Medicine and Science in Sports and Exercise, 12(3), 153-158. VIEW ITEM

Heikkinen, D. (2003). Physical testing characteristics and technical event performance of junior alpine ski racers (Master's thesis). Retrieved from University of Maine Electronic Theses and Dissertations. (ETD 473) VIEW ITEM

Hintermeister, R. A., O’Connor, D. D., Dillman, C. J., Suplizio, C. L., Lange, G. W., \& Steadman, R. J. (1995). Muscle activity in slalom and giant slalom skiing. Medicine and Science in Sports and Exercise, 27(3), 315-322. VIEW ITEM

Lešnik, B. (1996). Vrednotenje modela uspešnosti mlajših dečkov $v$ alpskem smučanju [Evaluation of the model of success of young boys in Alpine skiing]. (Unpublished master's thesis), Faculty of Sport, University of Ljubljana, Slovenia.

Mladenović, D., Cigrovski, V., Stanković, V., Prlenda, N., \& Uljević O. (2015). Success in adopting technique of alpine skiing with respect to motor abilities of the children aged 7-8 years. Collegium Antropologicum, 39(1), 77-82. VIEW ITEM

Šturm, R. (2012). Načrt otroškega programa smučanja [Plan of the children's ski program]. Retrieved from: http://www.sloski.si/resources/files/pdf/alpsko-smucanje/LETNI NART_ALPSKIH_REPREZENTANC_2012-2013_Vlado_Makuc_popravljen_mlad_ prog.pdf

Ušaj, A. (2003). Osnove športnega treniranja [Basics of sports training]. Unpublished manuscript, Faculty of Sport, University of Ljubljana, Slovenia. 